\title{
CHEMOSPHERE
}

\section{Comparisons of metal leachability for various wastes by extraction and leaching methods}

\author{
E.E. Chang ${ }^{\text {a,* }}$, P.C. Chiang ${ }^{\text {b }}$, P.H. Lu ${ }^{b}$, Y.W. Ko ${ }^{c}$ \\ a Department of Biochemistry, Taipei Medical University, 250 Wu-Hsing Street, Taipei 105, Taiwan, ROC \\ ${ }^{\mathrm{b}}$ Graduate Institute of Environmental Engineering, National Taiwan University, Taipei 106, Taiwan, ROC \\ ${ }^{c}$ Department of Environmental Engineering, Da-Yeh University, Chang-Hwa 515, Taiwan, ROC
}

Received 12 April 2000; received in revised form 19 September 2000; accepted 13 December 2000

\begin{abstract}
The objective of this research was to evaluate three extraction tests, i.e., toxicity characteristic leaching procedures (TCLP), extraction procedure (EP), and American Society for Testing and Materials (ASTM) methods, for their ability to extract metals in chemical sludge and incineration bottom ash, in terms of the precision of analytical results. Typical chemical sludges, including the electroplating and dye-stuff sludges, the municipal solid waste incineration bottom ash, the leather debris, and the steel-mill bottom residue containing $\mathrm{Cd}, \mathrm{Cr}, \mathrm{Cu}, \mathrm{Pb}$, and $\mathrm{Zn}$ were prepared for the lysimetry test (dynamic testing) to compare with the extraction results. Results show that for bottom residue and dye-stuff sludge, the concentration of metal leached was almost the same between the lysimetry leaching and the TCLP tests. The metal concentration followed the order: TCLP $\approx \mathrm{EP}>\mathrm{ASTM}$. TCLP and EP exhibited almost the same relative standard deviation (RSD) value. Therefore, the results of the TCLP tests for bottom residue and dye-stuff sludge, which have a low metal content and alkalinity, can be used to estimate the metal concentration leached by typical acid rain in Taiwan; whereas the ASTM extraction test may be a better indicator of the lysimetry test. (c) 2001 Elsevier Science Ltd. All rights reserved.
\end{abstract}

Keywords: American Society for Testing and Materials method; Extraction procedure; Lysimetry test; Toxicity characteristic leaching procedures

\section{Introduction}

Many testing procedures have been developed to simulate the leaching processes of hazardous wastes in landfills or natural environments in order to evaluate the possibility of human health hazard threats of tested wastes (ASTM, 1981; Federal Register, 1986; USEPA, 1986; Faellman, 1997). Comparisons of these suggested testing procedures, i.e., toxicity characteristic leaching

\footnotetext{
${ }^{*}$ Corresponding author. Tel.: +886-22736-9236; fax: +88622736-9236.

E-mail address: eechang@tmc.edu.tw (E.E. Chang).
}

procedures (TCLP), extraction procedure (EP), and American Society for Testing and Materials (ASTM) methods, for environmental sample analyses have been made elsewhere (Blackburn et al., 1988).

The EP test has been initially used to classify wastes as hazardous or non-hazardous. This test is designed to determine semi-volatile organic and heavy metal leachate concentrations; it does not however include an analysis of volatile organic compounds. The TCLP method is used by Environmental Protection Agency (EPA) of USA as the basis for the promulgation of the best demonstrated available technologies (BDAT) treatment standards under the land disposal restriction program. The EPA proposed that this test (1) replaces the EP test 
as the criterion for defining hazardous and non-hazardous waste and (2) is used for some listed wastes as the standard criterion for hazardous waste treatment. Generally, EP and TCLP methods yield similar leachate concentrations of metals. The study by Blackburn et al. (1988), however, indicates that TCLP extracts more metals. The statistical mean TCLP leachate concentrations ranged from 1.0 to 3.0 times greater than those for EP test. Hooper et al. (1998) reported that the TCLP roughly predicted the maximum concentrations extracted by the municipal solid waste leachates.

Additionally, it has also been noted that leaching might occur under either static or dynamic conditions, depending on the frequency of the leaching solution renewal. In static leaching tests, the leaching solution is not replaced, while in dynamic leaching tests, the leaching solution is periodically replaced with fresh solution. "Static" and "dynamic", therefore, refer to the velocity, not the chemistry of the leaching solution. The key difference between the dynamic leaching test and extraction tests (TCLP and EP) is that leaching tests generally take from weeks to years to complete whereas extraction tests are short-term tests lasting from hours to days. As a result, the column test is another type of laboratory leaching test which has been used along with extraction test to study the effects of particle size on the leaching of heavy metals (Bishop, 1986).

Since currently there is only provisional extraction procedure promulgated by Taiwan EPA, the standard operation procedure for solid wastes needs to be established and comparison of different extraction and leaching methods should be made. There has been very limited study on the effects of these testing methods on the precision of analytical results for industrial wastes. Therefore, the objective of this research was to evaluate three extraction tests (i.e., TCLP, EP, and ASTM methods) for their ability to extract metals in chemical sludges and incineration bottom ash, in terms of the precision of analytical results. Typical chemical sludges, including the electroplating and dye-stuff sludges, the municipal solid waste incineration bottom ash, the leather debris, and the steel-mill bottom residue containing $\mathrm{Cd}, \mathrm{Cr}, \mathrm{Cu}, \mathrm{Pb}$, and $\mathrm{Zn}$ were prepared for the lysimetry test (dynamic testing) to compare with the extraction results.

\section{Material and methods}

\subsection{Sample preparations}

The waste materials are from electroplating, textile (dye-stuff), leather, and steel-mill industries which are the major enterprises in the industrial parks in Taiwan. Because they are the typical wastes primarily concerned by the Taiwan EPA, they were chosen as the experi- mental materials in this investigation. Municipal solid waste incineration bottom ash was also used to undergo leaching (lysimetry test) and extraction testing (TCLP, EP, and ASTM). Three to five replicate samples under identical conditions were taken from the same batch of solid wastes. A preliminary study was performed to understand the concentration levels of heavy metals of interest in the chemical sludges and then to collect the appropriate amount of the above industrial wastes for the subsequent extraction and leaching tests.

\subsection{Extraction tests}

The above samples were prepared by crushing wastes to pass through a $9.5-\mathrm{mm}$ screen, while the liquids were separated from the solid phase by filtration through a $0.6-0.8 \mu \mathrm{m}$ borosilicate glass fiber filter under $50 \mathrm{psi}$ (340 $\mathrm{KPa}$ ). The primary difference among extraction tests was the leaching solutions used, which will be specified below. The leaching solution was added to a zero headspace extractor (ZHE) at a liquid:solid ratio of 20:1 and the sample was agitated in a National Bureau of Standards (NBS) rotary rumble at $30 \mathrm{rpm}$ for $18 \mathrm{~h}$. The leaching solution was filtered $(0.6-0.8 \mu \mathrm{m}$ glass fiber filter) and combined with the separated liquid waste fraction for metal analysis $(\mathrm{Cd}, \mathrm{Cr}, \mathrm{Cu}, \mathrm{Pb}$, and $\mathrm{Zn})$ in an atomic absorption flame spectrometer (Perkin-Elmer 5000). Two different buffered acidic leaching solutions were used in TCLP, depending on the alkalinity and the buffering capacity of the wastes: solution 1 had a $\mathrm{pH}$ of about 4.9; solution 2 had a $\mathrm{pH}$ of about 2.9. The $\mathrm{pH}$ levels of the samples were measured first to decide the appropriate leaching solution. According to the procedures specified by the US EPA, if $\mathrm{pH}$ is less than 5.0, solution 1 is used; otherwise solution 2 is used as the leaching solution. In this investigation, the leaching solution used in TCLP test was solution $2(\mathrm{pH}=2.9)$. For EP test, only one solution of acetic acid at $\mathrm{pH}$ of 5.0 was added periodically (up to specified maximum acidity) in order to adjust the $\mathrm{pH}$ level during the course of the extraction. For ASTM method (ASTM, 1985), the deionized water (Milli Q-SP) was used as the leaching solution.

\subsection{Leaching test-lysimeter}

Each lysimeter was placed outdoors and composed of an acrylic container with a dimension of $300 \mathrm{~mm} \times$ $3000 \mathrm{~mm} \times 300 \mathrm{~mm}$ in which $50 \mathrm{~mm}$ thickness of a layer of glass wool and plastic pellets was prepared to support the $15 \mathrm{~cm}$ thickness of the above prepared samples. A 5-1 bucket was used to collect rainwater which seeped through the lysimetry until a total of 201 of sample was obtained. The rain water in this experiment was taken in four batches at National Taiwan 
University, in Taipei, Taiwan. In the first batch, 1.93.11 were collected. In the second to the fourth batches, 3.2-4.2, 4.0-5.8, and 1.6-3.0 1 samples were prepared, respectively. This experiment on the elution of acid rain was carried out in May and June 1998, which is the "plum rain" season. It should be noted that in this investigation the $\mathrm{pH}$ value of the rainwater ranged from 4.9 to 5.2, indicating an acidic solution was maintained throughout the experiment. On the other hand, the $\mathrm{pH}$ value in the extraction solution prepared for the TCLP test was 2.9, which was lower than that in the natural rainwater.

At the end of the investigation, it was observed that the rainwater collected in the above four batches was not sufficient to make 201 as compared with the required volume for the TCLP test. Thus, it should be assumed that the metal concentration of the deficient amount was equivalent to that in the fourth batch. With this conservative assumption, the total amount of leaching solution from the acid rain test can be compared to that from the TCLP test on the same basis of an equal amount (20 1) of extraction solution.

The collected samples were filtered to determine the concentrations of $\mathrm{Cd}, \mathrm{Cr}, \mathrm{Cu}, \mathrm{Pb}$, and $\mathrm{Zn}$ and the results from the TCLP, EP, and ASTM tests were compared. All the analytical results were evaluated statistically.

\section{Results and discussion}

\subsection{Leachability of chemical sludges}

Table 1 shows the leachability of electroplating sludge by various methods. Results indicate that the final $\mathrm{pH}$ values determined by EP and TCLP methods were close and around 6.0. The final $\mathrm{pH}$ value using the ASTM method was between 8.3 and 9.7, with the exception of one sample of $\mathrm{pH}$ 7.4. It seemed that the amount of leachable metal was at the maximum level at neutral $\mathrm{pH}$. Extraction by TCLP and EP methods yielded greater $\mathrm{Cu}$ and $\mathrm{Zn}$ concentrations than that by the ASTM method. This may be attributed to the use of acetic acid in TCLP and EP tests. No significant difference was observed for $\mathrm{Pb}$ and $\mathrm{Cd}$ due to their trace content in the sludge samples.

The amounts of $\mathrm{Cu}$ and $\mathrm{Zn}$ leached by both the TCLP and EP methods were greater than allowed by leachability standards. The amounts of other elements leached were less than the leachability standard. The difference between these two extraction methods was insignificant. It can be concluded that $\mathrm{pH}$ plays an important role in the leachability of $\mathrm{Cu}$ and $\mathrm{Zn}$.

For those data sets containing at least one concentration that is under the detection limit in Table 1, the mean value and RSD were estimated using the simple

Table 1

Results of metal leachability for electroplating sludge determined by different methods ${ }^{\mathrm{a}}$

\begin{tabular}{|c|c|c|c|c|c|c|c|}
\hline \multirow[t]{2}{*}{ Method } & \multirow[t]{2}{*}{ Sample code } & \multicolumn{5}{|c|}{ Metal concentration (mg/l) } & \multirow[t]{2}{*}{ Final $\mathrm{pH}$} \\
\hline & & $\mathrm{Cd}$ & $\mathrm{Cr}$ & $\mathrm{Cu}$ & $\mathrm{Pb}$ & $\mathrm{Zn}$ & \\
\hline \multirow[t]{7}{*}{ TCLP } & AT-1 & $<0.04$ & 1.4 & 31 & $<0.32$ & 529 & 5.7 \\
\hline & AT-2 & $<0.04$ & 0.89 & 30 & $<0.32$ & 531 & 6.3 \\
\hline & AT-3 & $<0.04$ & 0.21 & 14 & $<0.32$ & 200 & 6.2 \\
\hline & AT-4 & $<0.04$ & 1.2 & 33 & $<0.32$ & 324 & 6.2 \\
\hline & AT-5 & $<0.04$ & 0.61 & 32 & $<0.32$ & 278 & 6.1 \\
\hline & Mean & $<0.04$ & 0.86 & 28 & $<0.32$ & 372 & - \\
\hline & RSD (\%) & - & 48 & 25 & - & 11 & - \\
\hline \multirow[t]{7}{*}{ EP } & AE-1 & $<0.04$ & 0.27 & 27 & $<0.32$ & 589 & - \\
\hline & AE-2 & $<0.04$ & 0.21 & 25 & $<0.32$ & 590 & - \\
\hline & AE-3 & $<0.04$ & $<0.10$ & 25 & $<0.32$ & 322 & 6.2 \\
\hline & AE-4 & $<0.04$ & 0.37 & 25 & $<0.32$ & 630 & 6.2 \\
\hline & AE-5 & $<0.04$ & $<0.10$ & 26 & $<0.32$ & 289 & 6.2 \\
\hline & Mean & $<0.04$ & 0.21 & 26 & $<0.32$ & 484 & - \\
\hline & RSD (\%) & - & 55 & 2 & - & 46 & - \\
\hline \multirow[t]{7}{*}{ ASTM } & AA-1 & $<0.04$ & $<0.10$ & 0.52 & $<0.32$ & 3.6 & 7.4 \\
\hline & AA-2 & $<0.04$ & 0.74 & 0.96 & $<0.32$ & 3.4 & 8.3 \\
\hline & AA-3 & $<0.04$ & 1.6 & 1.9 & $<0.32$ & 0.44 & 8.5 \\
\hline & AA-4 & $<0.04$ & 0.54 & 0.72 & $<0.32$ & 1.1 & 8.9 \\
\hline & AA-5 & $<0.04$ & 0.17 & 0.21 & $<0.32$ & 0.44 & 9.7 \\
\hline & Mean & $<0.04$ & 0.63 & 0.87 & $<0.32$ & 1.8 & - \\
\hline & RSD $(\%)$ & - & 96 & 77 & - & 58 & - \\
\hline
\end{tabular}

${ }^{\mathrm{a}}$ The leachability standards in Taiwan are: $\mathrm{Cd} 0.5 \mathrm{mg} / 1 ; \mathrm{Cr} 10.0 \mathrm{mg} / \mathrm{l} ; \mathrm{Cu} 15.0 \mathrm{mg} / \mathrm{l} ; \mathrm{Pb} 5.0 \mathrm{mg} / 1 ; \mathrm{Zn} 25.0 \mathrm{mg} / \mathrm{l}$. The detection limits in the analyses are: $\mathrm{Cd} 0.04 \mathrm{mg} / \mathrm{l} ; \mathrm{Cr} 0.10 \mathrm{mg} / \mathrm{l} ; \mathrm{Cu} 0.06 \mathrm{mg} / \mathrm{l} ; \mathrm{Pb} 0.32 \mathrm{mg} / \mathrm{l} ; \mathrm{Zn} 0.05 \mathrm{mg} / \mathrm{l}$. 
Table 2

Results of metal leachability for dye-stuff sludge determined by different methods

\begin{tabular}{|c|c|c|c|c|c|c|c|}
\hline \multirow[t]{2}{*}{ Method } & \multirow[t]{2}{*}{ Sample code } & \multicolumn{5}{|c|}{ Metal concentration (mg/l) } & \multirow[t]{2}{*}{ Final $\mathrm{pH}$} \\
\hline & & $\mathrm{Cd}$ & $\mathrm{Cr}$ & $\mathrm{Cu}$ & $\mathrm{Pb}$ & $\mathrm{Zn}$ & \\
\hline \multirow[t]{5}{*}{ TCLP } & DT-1 & $<0.04$ & $<0.10$ & $<0.06$ & $<0.32$ & 0.27 & 4.9 \\
\hline & DT-2 & $<0.04$ & $<0.10$ & $<0.06$ & $<0.32$ & 0.16 & 4.9 \\
\hline & DT-3 & $<0.04$ & $<0.10$ & $<0.06$ & $<0.32$ & 0.14 & 4.8 \\
\hline & Mean & $<0.04$ & $<0.10$ & $<0.06$ & $<0.32$ & 0.19 & - \\
\hline & RSD (\%) & - & - & - & - & 37 & - \\
\hline \multirow[t]{5}{*}{ EP } & DE -1 & $<0.04$ & $<0.10$ & $<0.06$ & $<0.32$ & 0.15 & 5.1 \\
\hline & DE-2 & $<0.04$ & $<0.10$ & $<0.06$ & $<0.32$ & 0.10 & - \\
\hline & DE-3 & $<0.04$ & $<0.10$ & $<0.06$ & $<0.32$ & 0.11 & 5.1 \\
\hline & Mean & $<0.04$ & $<0.10$ & $<0.06$ & $<0.32$ & 0.12 & - \\
\hline & RSD (\%) & - & - & - & - & 23 & - \\
\hline \multirow[t]{5}{*}{ ASTM } & DA-1 & $<0.04$ & $<0.10$ & $<0.06$ & $<0.32$ & $<0.05$ & 10.5 \\
\hline & DA-2 & $<0.04$ & $<0.10$ & $<0.06$ & $<0.32$ & $<0.05$ & 10.3 \\
\hline & DA-3 & $<0.04$ & $<0.10$ & $<0.06$ & $<0.32$ & $<0.05$ & 10.4 \\
\hline & Mean & $<0.04$ & $<0.10$ & $<0.06$ & $<0.32$ & $<0.05$ & - \\
\hline & RSD (\%) & - & - & - & - & - & - \\
\hline
\end{tabular}

substitution method (Helsel, 1990), and the detection limit concentration was used to represent the less-than values. Regarding the statistical treatment of data below the detection limit, the robust method suggested by Helsel (1990) was not used due to the very low data size in this study.

Results of metal leachability for dye-stuff sludge are shown in Table 2, which show that the final $\mathrm{pH}$ values were about $10.4,4.9$, and 5.1 by the ASTM, TCLP, and EP methods, respectively. During the course of EP testing, the $\mathrm{pH}$ decreased rapidly. The $\mathrm{pH}$ value reached 5.0 shortly after the extraction experiment and then remained relatively constant for the entire $28 \mathrm{~h}$. The amounts of $\mathrm{Cd}, \mathrm{Cr}, \mathrm{Cu}$, and $\mathrm{Pb}$ leached were lower than the detection limits, indicating the dye-stuff sludge has a low alkalinity and metal content. The average concentration of $\mathrm{Zn}$ leached was $0.19 \mathrm{mg} / \mathrm{l}$ by the TCLP method and $0.12 \mathrm{mg} / \mathrm{l}$ by the EP method, both of which were higher than those of ASTM method. Relative standard deviation (RSD) values among the methods were in the order of TCLP $(37 \%)$ $>$ EP $(23 \%)$. Since concentration of $\mathrm{Zn}$ leached by ASTM method was non-detectable, RSD value was not estimated.

\subsection{Leachability of municipal solid waste incineration bottom ash}

Table 3 shows the results of leaching of municipal solid waste incineration bottom ash, indicating that the EP test yielded final $\mathrm{pH}$ values (10.6-11.0) less than other methods. The TCLP test had a slightly higher final $\mathrm{pH}$ value (between 10.1 and 12.2); whereas the ASTM method yielded the highest final $\mathrm{pH}$ values (12.6).
Overall, the final $\mathrm{pH}$ values of the incinerated bottom ash were high by all leaching methods, indicating that the incinerated bottom ash was highly alkaline. The RSD values for $\mathrm{Pb}$ by the TCLP method was exceptionally high. This was because sample BT-2 showed a large amount of leached $\mathrm{Pb}$. The incineration bottom ash was obviously a heterogeneous matrix because of the different nature of municipal solid waste burnt in the incineration system.

Except for the sample BT-2 mentioned above, there are no other significant differences observed among various leaching methods. This may be attributed to the high alkalinity of the incineration bottom ash; even with the addition of acetic acid, the $\mathrm{pH}$ remained relatively constant. As a result, the amount of metal leached is small. Another possible reason is that the metal content of the incineration bottom ash is rather low. It was concluded that the amount of metal leached appeared to be below the leachability standard for all elements except lead.

\subsection{Leachability of steel-mill bottom residue}

As shown in Table 4, the $\mathrm{pH}$ value of the bottom residue from the steel-mill industry was alkaline, between 10.9 and 11.5 by the ASTM method (using the deionized water as the leaching solution). On the other hand, the $\mathrm{pH}$ levels using the acidic leaching solutions (for the TCLP and EP extraction tests) were around 5.0. This indicates that the bottom residue does not have a high acid neutralization capacity.

The amounts of $\mathrm{Zn}$ leached were below the leachability standards. The amounts of $\mathrm{Cd}, \mathrm{Cr}, \mathrm{Cu}$, and $\mathrm{Pb}$ leached were under the detection limits. Since the acid 
Table 3

Results of metal leachability for incineration bottom ash determined by different methods

\begin{tabular}{|c|c|c|c|c|c|c|c|}
\hline \multirow[t]{2}{*}{ Method } & \multirow[t]{2}{*}{ Sample code } & \multicolumn{5}{|c|}{ Metal concentration (mg/l) } & \multirow[t]{2}{*}{ Final $\mathrm{pH}$} \\
\hline & & $\mathrm{Cd}$ & $\mathrm{Cr}$ & $\mathrm{Cu}$ & $\mathrm{Pb}$ & $\mathrm{Zn}$ & \\
\hline \multirow[t]{5}{*}{ TCLP } & BT-1 & $<0.04$ & $<0.10$ & 0.44 & 3.9 & 0.10 & 12.2 \\
\hline & BT-2 & 0.05 & $<0.10$ & 0.55 & 76 & 0.24 & 12.0 \\
\hline & BT-3 & 0.06 & $<0.10$ & 0.33 & 0.38 & 0.08 & 10.1 \\
\hline & Mean & 0.05 & $<0.10$ & 0.44 & 27 & 0.14 & - \\
\hline & RSD (\%) & 20 & - & 25 & 160 & 62 & - \\
\hline \multirow[t]{5}{*}{ EP } & BE-1 & 0.05 & $<0.10$ & 0.54 & 3.0 & 0.46 & 10.6 \\
\hline & BE-2 & $<0.04$ & $<0.10$ & 0.62 & 1.8 & 0.51 & 11.0 \\
\hline & BE-3 & $<0.04$ & $<0.10$ & 0.62 & 2.7 & 0.83 & 11.0 \\
\hline & Mean & 0.04 & $<0.10$ & 0.59 & 2.5 & 0.60 & - \\
\hline & RSD (\%) & 13 & - & 8 & 24 & 34 & - \\
\hline \multirow[t]{5}{*}{ ASTM } & BA-1 & $<0.04$ & $<0.10$ & 0.60 & 7.7 & 1.0 & 12.6 \\
\hline & BA-2 & $<0.04$ & $<0.10$ & 0.62 & 5.0 & 0.90 & 12.6 \\
\hline & BA-3 & $<0.04$ & $<0.10$ & 0.51 & 5.9 & 0.95 & 12.6 \\
\hline & Mean & $<0.04$ & $<0.10$ & 0.58 & 6.2 & 0.96 & - \\
\hline & RSD (\%) & - & - & 10 & 22 & 7 & - \\
\hline
\end{tabular}

Table 4

Results of metal leachability for bottom residue from steel-mill bottom residue determined by different methods

\begin{tabular}{|c|c|c|c|c|c|c|c|}
\hline \multirow[t]{2}{*}{ Method } & \multirow[t]{2}{*}{ Sample code } & \multicolumn{5}{|c|}{ Metal concentration $(\mathrm{mg} / \mathrm{l})$} & \multirow[t]{2}{*}{ Final $\mathrm{pH}$} \\
\hline & & $\mathrm{Cd}$ & $\mathrm{Cr}$ & $\mathrm{Cu}$ & $\mathrm{Pb}$ & $\mathrm{Zn}$ & \\
\hline \multirow[t]{5}{*}{ TCLP } & CT-1 & $<0.04$ & $<0.10$ & $<0.06$ & $<0.32$ & $<0.05$ & 5.2 \\
\hline & CT-2 & $<0.04$ & $<0.10$ & $<0.06$ & $<0.32$ & 0.70 & 5.3 \\
\hline & CT-3 & $<0.04$ & $<0.10$ & $<0.06$ & $<0.32$ & 0.46 & 5.3 \\
\hline & Mean & $<0.04$ & $<0.10$ & $<0.06$ & $<0.32$ & 0.40 & - \\
\hline & RSD (\%) & - & - & - & - & 81 & - \\
\hline \multirow[t]{5}{*}{ EP } & CE-1 & $<0.04$ & $<0.10$ & $<0.06$ & $<0.32$ & 0.58 & 5.0 \\
\hline & CE-2 & $<0.04$ & $<0.10$ & $<0.06$ & $<0.32$ & 0.44 & 4.8 \\
\hline & CE-3 & $<0.04$ & $<0.10$ & $<0.06$ & $<0.32$ & 0.50 & 5.0 \\
\hline & Mean & $<0.04$ & $<0.10$ & $<0.06$ & $<0.32$ & 0.50 & - \\
\hline & RSD (\%) & - & - & - & - & 13 & - \\
\hline \multirow[t]{5}{*}{ ASTM } & CA-1 & $<0.04$ & $<0.10$ & $<0.06$ & $<0.32$ & 0.26 & 11.5 \\
\hline & CA-2 & $<0.04$ & $<0.10$ & $<0.06$ & $<0.32$ & 0.35 & 10.9 \\
\hline & CA-3 & $<0.04$ & $<0.10$ & $<0.06$ & $<0.32$ & 0.19 & 11.5 \\
\hline & Mean & $<0.04$ & $<0.10$ & $<0.06$ & $<0.32$ & 0.26 & - \\
\hline & RSD (\%) & - & - & - & - & 31 & - \\
\hline
\end{tabular}

neutralization capacity of bottom residue was small, the acetic acid added remained largely unneutralized. In spite of the resulting low $\mathrm{pH}$, the amount of metal leached was small indicating that the metal content of the bottom residue was intrinsically low, which is similar to the case of dye-stuff sludge.

The amount of $\mathrm{Zn}$ leached by the TCLP and EP methods were ND-0.70 mg/l and $0.44-0.58 \mathrm{mg} / \mathrm{l}$, respectively. The amount leached by the ASTM method was $0.19-0.35 \mathrm{mg} / \mathrm{l}$. In terms of RSD value, TCLP was the highest $(81 \%)$, followed by ASTM (31\%), with EP being the lowest $(13 \%)$. High RSD values may be attributed to the low amounts of metal leached.

\subsection{Leachability of leather debris}

Results shown in Table 5 indicate that the ASTM method yielded a final $\mathrm{pH}$ of 7.0. This was higher than the $\mathrm{pH}$ of 4.8 determined by the TCLP method and 4.75.1 by the EP method. The concentrations of $\mathrm{Cd}, \mathrm{Cu}$, and $\mathrm{Pb}$ leached were lower than the detection limits. The concentration of $\mathrm{Zn}$ leached was low, less than $0.24 \mathrm{mg} / \mathrm{l}$; whereas the concentration of $\mathrm{Cr}$ was high (between 6.6$30.9 \mathrm{mg} / \mathrm{l})$. The average concentrations of $\mathrm{Zn}$ by the TCLP method were $0.10 \mathrm{mg} / 1,0.18 \mathrm{mg} / \mathrm{l}$ by the EP method, and non-detectable by the ASTM method. The average concentration of $\mathrm{Cr}$ was the highest by the 
Table 5

Results of metal leachability of leather debris determined by different methods

\begin{tabular}{|c|c|c|c|c|c|c|c|}
\hline \multirow[t]{2}{*}{ Method } & \multirow[t]{2}{*}{ Sample code } & \multicolumn{5}{|c|}{ Metal concentration (mg/l) } & \multirow[t]{2}{*}{ Final $\mathrm{pH}$} \\
\hline & & $\overline{\mathrm{Cd}}$ & $\mathrm{Cr}$ & $\mathrm{Cu}$ & $\mathrm{Pb}$ & $\mathrm{Zn}$ & \\
\hline \multirow[t]{5}{*}{ TCLP } & ET-1 & $<0.04$ & 30 & $<0.06$ & $<0.32$ & 0.11 & 4.8 \\
\hline & ET-2 & $<0.04$ & 31 & $<0.06$ & $<0.32$ & 0.09 & 4.8 \\
\hline & ET-3 & $<0.04$ & 30 & $<0.06$ & $<0.32$ & 0.11 & 4.8 \\
\hline & Mean & $<0.04$ & 30 & $<0.06$ & $<0.32$ & 0.10 & - \\
\hline & RSD (\%) & - & 2 & - & - & 12 & - \\
\hline \multirow[t]{5}{*}{ EP } & EE-1 & $<0.04$ & 6.6 & $<0.06$ & $<0.32$ & 0.19 & 5.1 \\
\hline & EE-2 & $<0.04$ & 27 & $<0.06$ & $<0.32$ & 0.24 & 4.9 \\
\hline & EE-3 & $<0.04$ & 24 & $<0.06$ & $<0.32$ & 0.11 & 4.7 \\
\hline & Mean & $<0.04$ & 19 & $<0.06$ & $<0.32$ & 0.18 & - \\
\hline & RSD (\%) & - & 57 & - & - & 36 & - \\
\hline \multirow[t]{5}{*}{ ASTM } & EA-1 & $<0.04$ & $<0.10$ & $<0.06$ & $<0.32$ & $<0.05$ & 7.0 \\
\hline & EA-2 & $<0.04$ & $<0.10$ & $<0.06$ & $<0.32$ & $<0.05$ & 6.9 \\
\hline & EA-3 & $<0.04$ & $<0.10$ & $<0.06$ & $<0.32$ & $<0.05$ & 6.9 \\
\hline & Mean & $<0.04$ & $<0.10$ & $<0.06$ & $<0.32$ & $<0.05$ & - \\
\hline & RSD $(\%)$ & - & - & - & - & - & - \\
\hline
\end{tabular}
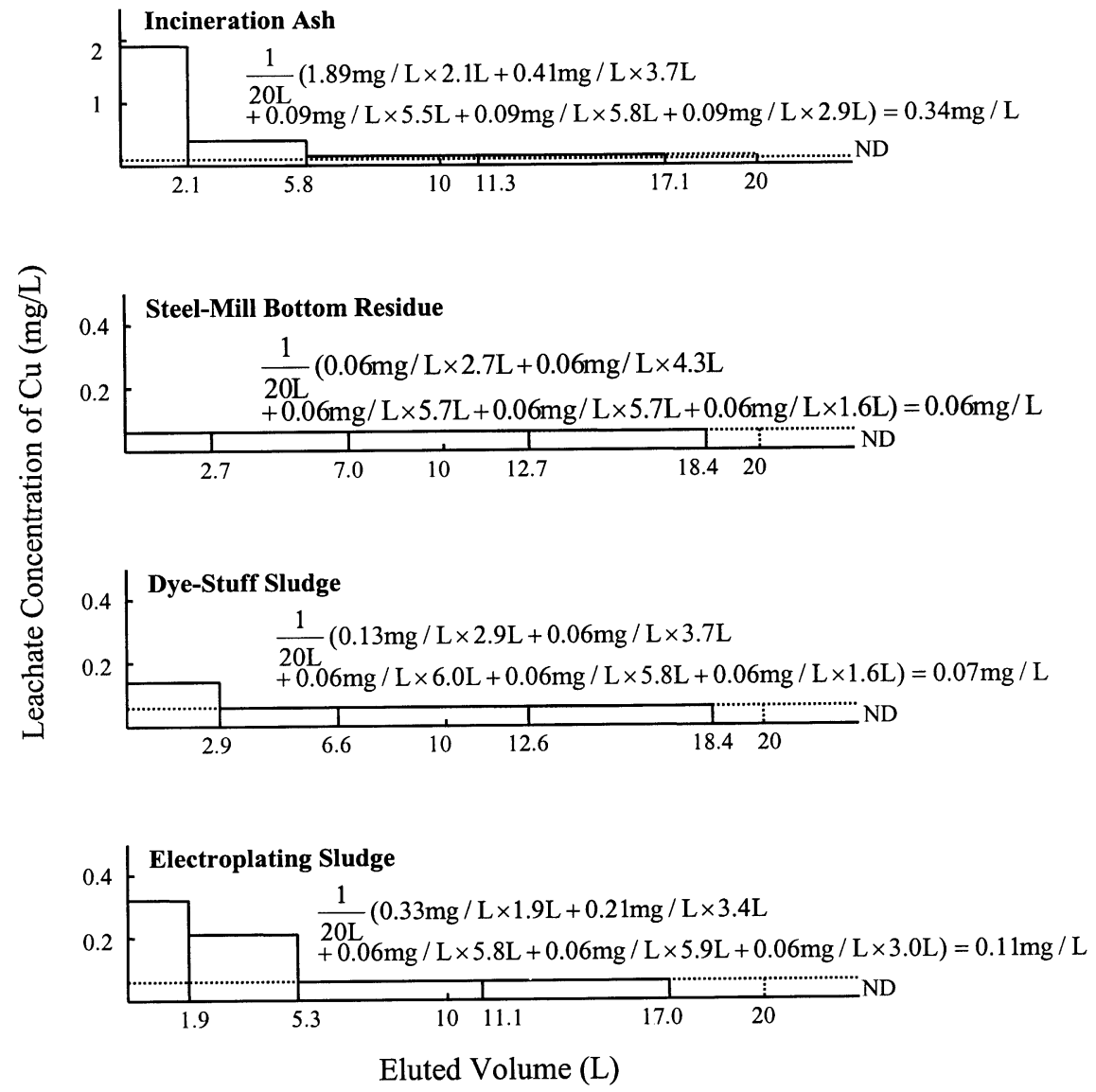

Fig. 1. Concentration of $\mathrm{Cu}$ in each eluted samples for different industrial waste during the lysimetry test. 
TCLP $(30.1 \mathrm{mg} / \mathrm{l})$ method followed by the EP method $(19.2 \mathrm{mg} / \mathrm{l})$. The concentration of $\mathrm{Cr}$ by the ASTM method was below the limit of detection. Results indicate that $\mathrm{pH}$ plays an important role in the leachability of $\mathrm{Cr}$.

\subsection{Lysimetry experiments}

The metal concentration in each eluted sample during the lysimetry experiments was measured. The results showed two types of elution curves, i.e., an exponential decay curve $(\mathrm{Cu}, \mathrm{Zn}$, and $\mathrm{Cr})$ and a bell curve $(\mathrm{Cd}$ and $\mathrm{Pb}$ ). The elution concentration curves of $\mathrm{Cu}$ and $\mathrm{Cd}$ and calculations are presented in Figs. 1 and 2, respectively, indicating the concentration of $\mathrm{Cu}$ and $\mathrm{Cd}$ leached from different types of industrial waste during the lysimetry test. The results of this estimation were compared with the findings obtained form the TCLP test and are given in Table 6.

Table 6 shows the results of metal leached by the lysimeter and the TCLP experiments. Results show that for bottom residue and dye-stuff sludge, the concentration of metal leached was almost the same between the lysimetry leaching and the TCLP tests, except the $\mathrm{Zn}$ concentration in the steel-mill bottom residue. Not only is the $\mathrm{pH}$ of rainwater and leaching solution of TCLP different, the buffer capacity of the rainwater and leaching solution is also far different. For the samples with a low metal content and low alkalinity, these two methods may yield similar results. Therefore, the results of the TCLP tests for bottom residue and dye-stuff sludge, which have a low metal content and alkalinity, can be used to estimate the metal concentration leached by typical acid rain in Taiwan. However, for the electroplating sludge, the TCLP method yielded a higher metal concentration than the lysimetry test. The concentrations of $\mathrm{Cu}$ and $\mathrm{Zn}$ as determined by the TCLP method were much higher than that by the lysimetry test in some cases. In addition, apparently metal concentrations obtained by the TCLP method were rather high, which is consistent with the general principles, TCLP always presents the maximum leachate concentration for environmental samples.

Because these sludge samples are generally from hydroxide precipitation processes, the above phenomena could be interpreted by the fact that the relatively lower
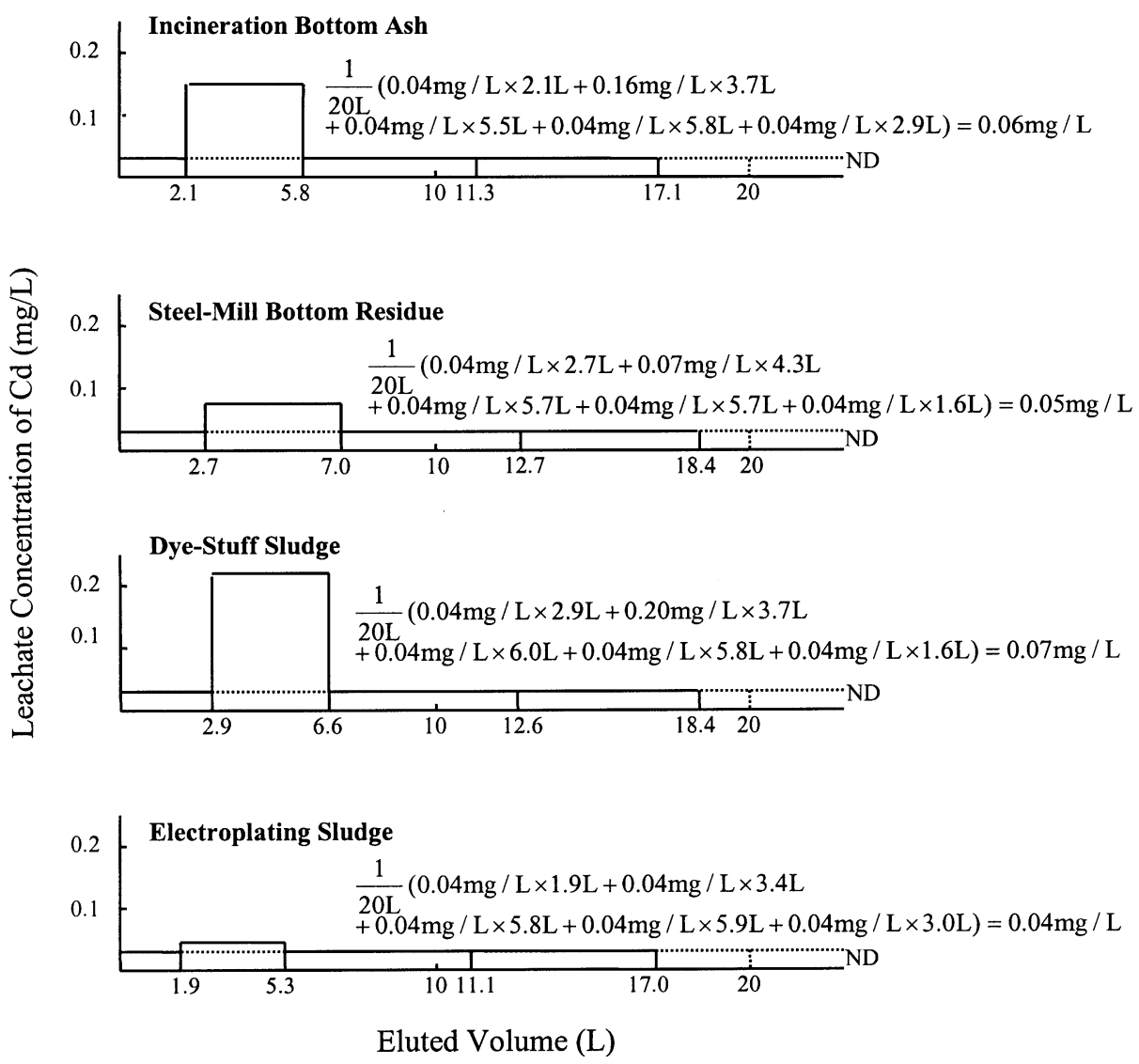

Fig. 2. Concentration of $\mathrm{Cd}$ in each eluted samples for different industrial waste during the lysimetry test. 
Table 6

Comparison of results of metal leachability for various wastes by TCLP and lysimetry leaching tests (LLT)

\begin{tabular}{|c|c|c|c|c|c|c|c|}
\hline \multirow[t]{2}{*}{ Types of waste } & \multirow[t]{2}{*}{ Method } & \multirow[t]{2}{*}{ Sample code } & \multicolumn{5}{|c|}{ Metal concentration (mg/l) } \\
\hline & & & $\mathrm{Cd}$ & $\mathrm{Cr}$ & $\mathrm{Cu}$ & $\mathrm{Pb}$ & $\mathrm{Zn}$ \\
\hline \multicolumn{8}{|c|}{ Incineration bottom ash } \\
\hline & TCLP & BT & 0.05 & $<0.10$ & 0.44 & 27 & 0.14 \\
\hline & LLT & LLT-1 & 0.06 & $<0.10$ & 0.34 & 0.45 & $<0.05$ \\
\hline & & LLT-2 & 0.06 & $<0.10$ & 0.33 & 0.43 & $<0.05$ \\
\hline & & Average & 0.06 & $<0.10$ & 0.34 & 0.44 & $<0.05$ \\
\hline & & TCLP/Average & 0.83 & a & 1.3 & 60.4 & - \\
\hline \multicolumn{8}{|c|}{ Steel-mill bottom residue } \\
\hline & TCLP & $\mathrm{CT}$ & $<0.04$ & $<0.10$ & $<0.06$ & $<0.32$ & 0.40 \\
\hline & LLT & LLT-1 & 0.05 & $<0.10$ & $<0.06$ & 0.42 & 0.06 \\
\hline & & LLT-2 & $<0.04$ & $<0.10$ & $<0.06$ & 0.44 & $<0.05$ \\
\hline & & Average & 0.05 & $<0.10$ & $<0.06$ & 0.43 & 0.06 \\
\hline & & TCLP/Average & - & a & a & - & 6.7 \\
\hline \multicolumn{8}{|l|}{ Dye-stuff sludge } \\
\hline & TCLP & DT & $<0.04$ & $<0.10$ & $<0.06$ & $<0.32$ & 0.19 \\
\hline & LLT & LLT-1 & 0.07 & $<0.10$ & 0.07 & 0.50 & 0.1 \\
\hline & & LLT-2 & 0.07 & $<0.10$ & $<0.06$ & 0.40 & 0.3 \\
\hline & & Average & 0.07 & $<0.10$ & 0.07 & 0.45 & 0.2 \\
\hline & & TCLP/Average & - & a & - & - & 0.9 \\
\hline \multicolumn{8}{|c|}{ Electroplating sludge } \\
\hline & TCLP & AT & $<0.04$ & 0.92 & 28 & $<0.32$ & 372 \\
\hline & LLT & LLT-1 & $<0.04$ & $<0.10$ & 0.11 & 0.42 & 0.06 \\
\hline & & LLT-2 & $<0.04$ & $<0.10$ & 0.14 & 0.43 & $<0.05$ \\
\hline & & Average & $<0.04$ & $<0.10$ & 0.13 & 0.43 & 0.06 \\
\hline & & TCLP/Average & a & - & 215 & - & 6200 \\
\hline
\end{tabular}

${ }^{\mathrm{a}}$ Both the metal concentrations from the TCLP and LLT are non-detectable (ND).

solubility product of hydroxide associated with $\mathrm{Cu}$ and $\mathrm{Zn}$ was observed as follows:

$$
\begin{aligned}
\mathrm{Cd}\left(10^{-13.6}\right) & >\mathrm{Pb}\left(10^{-14.93}\right)>\mathrm{Zn}\left(10^{-16.92}\right) \\
& >\mathrm{Cu}\left(10^{-19.66}\right)
\end{aligned}
$$

Table 7 presents the comparison of metal leachability in various types of industrial waste by different extraction tests. It can be seen that when the metal content is high, such as for $\mathrm{Cu}$ and $\mathrm{Zn}$ in electroplating sludge and $\mathrm{Cr}$ in leather debris, the addition of acetic acid can affect the concentration of metal leached. As a result, the metal concentration followed the order: TCLP $\approx \mathrm{EP}>$ ASTM. When the metal content was low, such as for $\mathrm{Cu}$ and $\mathrm{Zn}$ in incineration bottom ash, bottom residue, dyestuff sludge, and leather debris, the concentrations of

Table 7

\begin{tabular}{|c|c|c|c|c|c|}
\hline $\begin{array}{l}\text { Water quality } \\
\text { parameters }\end{array}$ & $\begin{array}{l}\text { Electroplating } \\
\text { sludge }\end{array}$ & Dye-stuff sludge & $\begin{array}{l}\text { Incineration } \\
\text { bottom ash }\end{array}$ & $\begin{array}{l}\text { Steel-mill } \\
\text { bottom residue }\end{array}$ & Leather debris \\
\hline $\mathrm{pH}$ & $\begin{array}{l}\text { ASTM }>\text { EP } \\
\approx \text { TCLP }\end{array}$ & $\begin{array}{l}\text { ASTM }>\text { EP } \\
\approx \text { TCLP }\end{array}$ & $\begin{array}{l}\text { ASTM }>\text { EP } \\
\approx \text { TCLP }\end{array}$ & $\begin{array}{l}\text { ASTM }>\text { EP } \\
\approx \text { TCLP }\end{array}$ & $\begin{array}{l}\text { ASTM }>\text { EP } \\
\approx \text { TCLP }\end{array}$ \\
\hline $\mathrm{Cd}$ & ND & ND & ND & ND & ND \\
\hline $\mathrm{Cr}$ & $\begin{array}{l}\mathrm{TCLP} \approx \mathrm{ASTM}> \\
\mathrm{EP}\end{array}$ & ND & ND & ND & $\begin{array}{l}\text { TCLP }>\text { EP }> \\
\text { ASTM }\end{array}$ \\
\hline $\mathrm{Cu}$ & $\begin{array}{l}\text { TCLP } \approx \mathrm{EP} \\
>\mathrm{ASTM}\end{array}$ & ND & $\begin{array}{l}\mathrm{EP} \approx \mathrm{ASTM} \\
\approx \mathrm{TCLP}\end{array}$ & ND & ND \\
\hline $\mathrm{Pb}$ & ND & ND & $\mathrm{ASTM}>\mathrm{EP}$ & ND & ND \\
\hline $\mathrm{Zn}$ & $\begin{array}{l}\mathrm{TCLP} \approx \\
\mathrm{EP}>\mathrm{ASTM}\end{array}$ & $\begin{array}{l}\text { TCLP } \approx \mathrm{EP}> \\
\text { ASTM }\end{array}$ & $\begin{array}{l}\text { ASTM }>\text { EP } \\
>\text { TCLP }\end{array}$ & $\begin{array}{l}\mathrm{TCLP} \approx \mathrm{EP} \\
>\mathrm{ASTM}\end{array}$ & $\begin{array}{l}\text { TCLP } \approx \mathrm{EP}> \\
\mathrm{ASTM}\end{array}$ \\
\hline
\end{tabular}

Comparison of metal leachability in various wastes by different extraction tests 
metal leached out by the three methods were almost identical. In addition, the final $\mathrm{pH}$ values by the TCLP and EP methods were close and generally lower than those of the ASTM method.

On the other hand, TCLP and EP exhibited almost the same RSD value. Since the TCLP method is less labor-intensive, it suggests that TCLP should be employed as the major method of testing for leachability for the wastes having a low metal content and alkalinity; whereas, the ASTM extraction test may be a better indicator of the short-term lysimetry test.

\section{Conclusions}

As for metal leachability in various wastes by different extraction tests, the metal concentration followed the order: TCLP $\approx \mathrm{EP}>\mathrm{ASTM}$. TCLP and EP exhibited almost the same RSD value. When the metal content was low, such as for $\mathrm{Cu}$ and $\mathrm{Zn}$ in incineration bottom ash, bottom residue, dye-stuff sludge, and leather debris, the concentrations of metal leached out by the three methods were almost identical. On the other hand, when the metal content is high, such as for $\mathrm{Cu}$ and $\mathrm{Zn}$ in electroplating sludge and $\mathrm{Cr}$ in leather debris, the addition of acetic acid can affect the concentration of metal leached.

Results show that for bottom residue, incineration bottom ash, and dye-stuff sludge, the concentration of metal leached was almost the same between the lysimetry leaching and the TCLP tests. Since the TCLP method is less labor-intensive, it suggests that TCLP should be employed as the major method of testing for leachability for the wastes having a low metal content and alkalinity; whereas, the ASTM extraction test may be a better indicator of the short-term lysimetry test.

\section{References}

ASTM, 1981. Standard Methods for Chemical Analysis of Hydraulic Cement. Committee C-1 on Cement, Philadelphia, Pennsylvania.

ASTM, 1985. Standard Test Method for Shake Extraction of Solid Waste with Water. ASTM D3987-85, pp. 24-27.

Bishop, P.L., 1986. Prediction of heavy metal leaching rates from stabilized/solidified hazardous wastes, in toxic and hazardous wastes. In: Proceedings of the 18th Mid-Atlantic Industrial Waste Conference, pp. 236-252.

Blackburn, W.B., Show, I., Taylor, D.R., Marden, P.J., 1988. Collaborative Study of the Toxicity Characteristic Leaching Procedure (TCLP). EPA/600/4-87/045, PB88-165691.

Faellman, A.-M., 1997. Performance and design of the availability test for measurement of potentially leachable amounts from waste materials. Environ. Sci. Technol. 31, 735-744.

Federal Register, 1986. Toxicity Characteristic Leaching Procedure (TCLP). November 7, 51: 216.

Helsel, D.R., 1990. Less than obvious: statistical treatment of data below the detection limit. Environ. Sci. Technol. 24, $1766-1774$.

Hooper, K., Iskander, M., Sivia, G., Hussein, F., Hsu, J., Deguzman, M., Odion, Z., Ilejay, Z., Sy, F., Petreas, M., Simmons, B., 1998. Toxicity characteristic leaching procedure fails to extract oxoanion-forming elements that are extracted by municipal solid waste leachates. Environ. Sci. Technol. 32, 3825-3830.

US EPA, 1986. Test Methods for Evaluating Solid Waste. SW 846, third ed. Office of Solid Waste, Washington DC. 